\title{
Commentary: The impact of climate change on landslides in southeastern of high-latitude permafrost regions of China
}

\author{
Fabio Matano * \\ Institute for Coastal Marine Environment, National Research Council, Naples, Italy
}

Keywords: climate change, permafrost degradation, landslides, permafrost related hazard, high latitude regions

\section{A commentary on}

The impact of climate change on landslides in southeastern of high-latitude permafrost regions of China

by Shan, W., Hu, Z., Guo, Y., Zhang, C., Wang, C., Jiang, H., et al. (2015). Front. Earth Sci. 3:7. doi: 10.3389/feart.2015.00007

OPEN ACCESS

Edited by:

Davide Tiranti,

Regional Agency for Environmental

Protection of Piemonte, Italy

Reviewed by:

R. M. Yuan,

Institute of Geology, China Earthquake

Administration, China

*Correspondence:

Fabio Matano

fabio.matano@cnr.it

Specialty section:

This article was submitted to

Quaternary Science, Geomorphology

and Paleoenvironment,

a section of the journal

Frontiers in Earth Science

Received: 21 January 2016

Accepted: 15 February 2016

Published: 24 February 2016

Citation:

Matano F (2016) Commentary: The impact of climate change on

landslides in southeastern of

high-latitude permafrost regions of

China. Front. Earth Sci. 4:22.

doi: 10.3389/feart.2016.00022
Permafrost is defined as "ground remaining at or below $0{ }^{\circ} \mathrm{C}$ for at least two consecutive years" (van Everdingen, 2005). The definition itself stresses that the permafrost should not be considered as a permanent thermal state, because it is extremely vulnerable to natural and man-induced climatic and environmental changes on different spatial and temporal scales. More in detail, the process of degradation, i.e., the fall in permafrost temperature within it (Dobinski, 2011), may entail several effects on permafrost (lowering of the table, raising of the base, thickening of the active layer) with a resulting reduction of its areal extent up to the complete disappearance with severe consequences on the stability of slopes and infrastructures.

In the high-latitude permafrost regions of northern hemisphere, permafrost degradation is occurring under current climate warming (Osterkamp, 2005; Anisimov and Reneva, 2006). One of the most important effects of climate changes in these regions is the progressive modification of the permafrost thermal regime, and hence its physical properties and distribution, beyond the range of variability documented in historical archives (Harris et al., 2009). The mode of permafrost degradation is highly variable, and its consequences on geomorphological conditions and engineering infrastructures depend on the interaction of slope position and aspect, soil and ground type, vegetation cover, hydrology, and ice content (Nelson et al., 2001). Some future projections (Lawrence and Slater, 2005) predict a severe permafrost degradation during twentyfirst century with a reduction up to about $90 \%$ of the near-surface permafrost total area, excluding ice sheets, in circum-Arctic regions of Eurasia and North America.

In the high-latitude permafrost regions of China, climate change is leading to permafrost degradation at a greater extent, as testified by the occurrences of shrinking areas of permafrost, increasing depth of the active layer, rising of lower latitudinal limit of permafrost, and thinning of the seasonal frost (Li et al., 2008; He et al., 2009). Due to the combined influence of climatic warming and increasing anthropogenic activities, further substantial retreat of permafrost is specifically expected on the Qinghai-Tibetan Plateau and in northeastern China during the twenty-first century (Jin et al., 2000). Therefore, permafrost degradation has and will have great influence on engineering construction, water resources and environments in the cold regions of China. 
Starting from the scenario of generalized permafrost degradation due to climate warming, the study of Shan et al. (2015) intends to investigate the impact of climate change on landslides in the high-latitude permafrost regions of northeast China. Their study concerns to a narrow area located at the extreme southern fringe of high-latitude permafrost Asian regions, characterized by an island-like permafrost type, which is far away more than $500 \mathrm{~km}$ from not degraded permafrost regions in Greater Khingan Mts. The study area is located in Sunwu County, where Bei'anHeihe highway intersects the northwest section of the Lesser Khingan Mts., and is characterized by extremely unstable geological conditions, because the permafrost is the result of a residual paleoglacial deposition and the remaining islandlike permafrost areas are currently under severe degradation conditions.

The climate change is documented by the last 60 years meteorological data at Sunwu County. The average annual air temperature has increased $3.2^{\circ} \mathrm{C}$, passing from about $-2^{\circ} \mathrm{C}$ to about $+1^{\circ} \mathrm{C}$, while the average annual minimum temperature has increased a lot more, in the amount of $5.2^{\circ} \mathrm{C}$ during the same time period, passing from about $-10^{\circ} \mathrm{C}$ to about $-5^{\circ} \mathrm{C}$. The seasonal ground freezing in the study area reaches maximum depth at the end of May with maximum depth of $2.67 \mathrm{~m}$; ground temperature at $40 \mathrm{~cm}$ of depth ranges between $-9^{\circ} \mathrm{C}$ and $+16^{\circ} \mathrm{C}$, and the ground is frozen only 6 mouths during a year.

The degraded permafrost is highly sensitive under the described climatic conditions and any advancement in degradation conditions due to ongoing climate warming or human action may lead to further reduction in the stability of mountain slopes and in an increase of permafrost-related hazards.

Shan et al. (2015) recognizes that the progress in permafrost degradation results both in an growing number of landslides and in a faster evolution of the already occurring significant landslides in the study area. More in detail, they describe a model of landslide evolution driven by the increase in pore water pressure for the seepage of water from permafrost thawing into the landslide mass on the basis of engineering

\section{REFERENCES}

Anisimov, O., and Reneva, S. (2006). Permafrost and changing climate: the Russian perspective. Ambio 35, 169-175. doi: 10.1579/00447447(2006)35[169:PACCTR]2.0.CO;2

Dobinski, W. (2011). Permafrost. Earth Sci. Rev. 108, 158-169. doi: 10.1016/j.earscirev.2011.06.007

Harris, C., Arenson, L. U., Christiansen, H. H., Etzelmüller, B., Frauenfelder, R., Gruber, S., et al. (2009). Permafrost and climate in Europe: Monitoring and modelling thermal, geomorphological and geotechnical responses. Earth Sci. Rev. 92, 117-171. doi: 10.1016/j.earscirev.2008.12.002

Harris, C., Davies, M. C. R., and Etzelmüller, B. (2001). The assessment of potential geotechnical hazards associated with mountain permafrost in a warming global climate. Permafrost Periglacial Process. 12, 145-156. doi: 10.1002/ppp.376

He, R. X., Jin, H. J., Chang, X. L., Lv, L. Z., Yu, S. P., Yang, S. Z., et al. (2009). Degradation of permafrost in the northern part of northeastern China: present geological studies and monitoring data related to a representative landslide.

The problems analyzed in Shan et al. (2015) are very complex and deserve further in-depth analysis for deciphering the different causes of permafrost degradation and related landslides. The authors recognize in their study area the connection between climate changes and permafrost degradation, that is well-established in literature for the whole northern hemisphere permafrost regions. Then they describe a relationship between permafrost degradation and landslide events in the study area, but the direct link between climate changes and the occurrence of landslide events has not been fully explained.

Shan et al. (2015) consider human engineering projects further accelerating the process of permafrost degradation due to climate change, and more in detail they hypothesize that acceleration in permafrost thawing may be also induced by the Bei'an-Heihe Highway extension project but without trying to quantify or verify this effect. The interaction between the effects of ongoing climate change and construction of the highway on the permafrost conditions is not addressed in the study. Also the slope instabilities along not frozen slope sections induced by highway construction and extension works should be considered.

One of the greatest challenges facing geocryologists remains to separate climate-induced impacts from local anthropogenic influences (Nelson, 2003), as not all changes in permafrost, and not all related landslides, can be directly ascribed to climate change. In wider terms, construction and upkeep of mountain infrastructures in degraded permafrost terrain is an engineering challenge, also because climatically-driven changes in the thermal status and spatial distribution of permafrost are leading to severe perturbation of their dynamic equilibria, which are causing widening of permafrost-related hazard zones (Harris et al., 2001, 2009).

\section{AUTHOR CONTRIBUTIONS}

The author confirms being the sole contributor of this work and approved it for publication. state and causal analysis. J. Glaciol. Geocryol. 31, 829-834. Available online at: http://bcdt.westgis.ac.cn/EN/volumn/volumn_1146_abs.shtml

Jin, H., Li, S., Guodong, C., Shaoling, W., and Li, X. (2000). Permafrost and climatic change in China. Glob. Planet. Change 26, 387-404. doi: 10.1016/S09218181(00)00051-5

Lawrence, D. M., and Slater, A. G. (2005). A projection of severe near-surface permafrost degradation during the 21st century. Geophys. Res. Lett. 32, L24401. doi: 10.1029/2005GL025080

Li, X., Cheng, G., Jin, H., Kang, E., Che, T., Jin, R., et al. (2008). Cryospheric change in China. Glob. Planet. Change 62, 210-218. doi: 10.1016/j.gloplacha.2008.02.001

Nelson, F. (2003). (Un)frozen in time. Science 299, 1673-1675. doi: $10.1126 /$ science. 1081111

Nelson, F. E., Anisimov, O. A., and Shiklomanov, N. I. (2001). Subsidence risk from thawing permafrost. Nature 410, 889-890. doi: 10.1038/350 73746 
Osterkamp, T. (2005). The recent warming of permafrost in Alaska. Glob. Planet. Change 49, 187-202. doi: 10.1016/j.gloplacha.2005. 09.001

Shan, W., Hu, Z., Guo, Y., Zhang, C., Wang, C., Jiang, H., et al. (2015). The impact of climate change on landslides in southeastern of high-latitude permafrost regions of China. Front. Earth Sci. 3:7. doi: 10.3389/feart.2015. 00007

van Everdingen, R. (2005). Multi-Language Glossary of Permafrost and Related Ground-Ice Terms. 1998 revised May 2005. Boulder, CO: National Snow and Ice Data Center. Available online at: https://nsidc.org/fgdc/glossary/
Conflict of Interest Statement: The author declares that the research was conducted in the absence of any commercial or financial relationships that could be construed as a potential conflict of interest.

Copyright (ङ 2016 Matano. This is an open-access article distributed under the terms of the Creative Commons Attribution License (CC BY). The use, distribution or reproduction in other forums is permitted, provided the original author(s) or licensor are credited and that the original publication in this journal is cited, in accordance with accepted academic practice. No use, distribution or reproduction is permitted which does not comply with these terms. 